\title{
Healthy eating in Ukraine: attitudes, barriers and information sources
}

\author{
OO Biloukha and V Utermohlen* \\ Division of Nutritional Sciences, Cornell University, lthaca, NY 14853, USA
}

\begin{abstract}
Objective: To identify the major perceived influences on food choice, to examine the use of and trust in information sources concerning healthy eating, and to assess attitudes towards and barriers to adopting healthy eating practices in a post-USSR country (Ukraine).

Design: A survey of an urban adult population. The questions were adopted from the Pan-European Union (EU) Survey of Consumer Attitudes to Food, Nutrition and Health (1995-1996).

Setting: Lviv city, Ukraine.

Subjects: The survey included 296 adults (84 males, 212 females) aged 18-55 years; they were primarily college students and subjects with tertiary education - the groups most likely to be both interested in healthy eating and affected by current socioeconomic downturns.

Results: The major factors in food choice were: 'quality/freshness' (cited by 80\%), 'price' (58\%) and 'taste' (47\%); only 34\% cited 'trying to eat healthily'. More older people cited 'price' than 'quality/freshness', and men were more likely than women to cite 'taste'. Sources of healthy eating information included: 'relatives/friends' (cited by $65 \%$, trusted by $85 \%$ ) and health professionals (trusted by $92 \%$, but used by only $35 \%$ ); while advertising was the least trusted source (cited by $28 \%$ ). Fifty-three per cent of respondents considered their diet to be healthy enough without further changes; $50 \%$ thought of the nutritional aspects of the food they ate; fewer women than men considered their diet healthy, and more women than men thought about nutrition. Barriers to healthy eating included: 'cost' (cited by 65\%), 'lack of time' (55\%), 'self-control' (54\%), 'selection influences' (41\%), 'lack of knowledge' (32\%), 'unpleasant foods' and 'resistance to change' (both 30\%).

Conclusions: Strategies to encourage healthy eating in this population should involve word-of-mouth nutrition education concerning low-cost healthy alternatives.
\end{abstract}

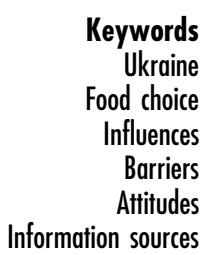

The purpose of this pilot study was to identify major perceived influences on food choice; examine the use of and trust in information sources concerning healthy eating; and assess attitudes towards and barriers to adopting healthy eating practices, in an urban population in the Ukraine. The Ukraine is part of the Commonwealth of Independent States (CIS) which includes 12 of the 15 former Republics of the Soviet Union, excluding the three Baltic states.

Over the past decade, the CIS countries have experienced significant increases in age-specific mortality rates and declines in life expectancy ${ }^{1}$. These trends are primarily due to increased morbidity and mortality from cardiovascular disease, particularly in the European part of the CIS ${ }^{2}$. Cockerham ${ }^{3}$ concluded, after examining the effects of Soviet health policy, social stress and lifestyle, that the unhealthy lifestyles of the CIS populations may be at fault.

These unhealthy lifestyles include suboptimal diets, lack of exercise and heavy smoking and drinking. Popkin and his colleagues, as well as Cockerham, point to a diet rich in animal fats and poor in fruits and vegetables, especially in winter, as a major contributor to this increase in mortality ${ }^{3,4}$. To support their contention, they point to data from the Russian Longitudinal Monitoring Survey conducted in 1992-1993, which showed that the per cent of daily energy intake derived from fat was in the range of $34-38 \%{ }^{4}$, substantially higher than the recommended upper limit of $30 \%$ for the US population.

Three major factors have contributed to high fat intakes in Ukraine, Russia and other CIS countries. First, as discussed by Popkin et al. ${ }^{4}$, the Soviet Union's economic 
Table 1 Sociodemographic characteristics of the subjects

\begin{tabular}{lccc}
\hline & All $(n=296)$ & Men $(n=84)$ & Women $(n=212)$ \\
\hline Age: mean \pm SD (median) & $25.8 \pm 9.8(19.5)$ & $24.7 \pm 9.7(19)$ & $26.2 \pm 9.8(21)$ \\
18-25 years & $178(60.1 \%)$ & $57(67.9 \%)$ & $121(57.1 \%)$ \\
$26-35$ years & $62(20.9 \%)$ & $9(10.7 \%)$ & $53(25.0 \%)$ \\
$36-55$ years & $56(18.9 \%)$ & $18(21.4 \%)$ & $38(17.9 \%)$ \\
& & & \\
Education & $31(10.5 \%)$ & $2(2.4 \%)$ & $29(13.7 \%)$ \\
Secondary or 1-2 years beyond & $103(34.8 \%)$ & $28(33.3 \%)$ & $75(35.4 \%)$ \\
$\quad$ Tertiary & $162(54.7 \%)$ & $54(64.3 \%)$ & $108(50.9 \%)$ \\
Student (college or university) & & & \\
Employment status (non-students) & $87(29.4 \%)$ & $20(23.8 \%)$ & $67(31.6 \%)$ \\
$\quad$ Employed & $47(15.9 \%)$ & $10(11.9 \%)$ & $37(17.5 \%)$ \\
$\quad$ Unemployed & & & \\
\hline
\end{tabular}

and agricultural policies from the early 1960s to the $1980 \mathrm{~s}$ were directed at increasing production of meats, dairy products and sugar, because production of these foods was associated with improving economic status. Therefore, while there were large increases in per capita production of these foods from the 1960s through the 1980s, the per capita production of the major staple starches (potatoes and bread) decreased.

Second, the recommended daily protein intake in the former USSR $^{5}$ was about 1.6 times greater than the present US recommended daily allowance (RDA) ${ }^{6}$. Moreover, dietary guidelines specifically emphasized the importance of animal protein, suggesting that it should account for at least $55-60 \%$ of the total protein consumed ${ }^{5}-$ this level of $^{2}$ protein intake is usually accompanied by a substantial intake of fat.

Third, the Ukrainian, Russian and Polish food cultures value animal products highly. From personal experience (OOB) in Ukraine, meats and dairy products are not only considered to be tasty, healthy and nutritious, but are also regarded as an essential part of the national cuisine and culture.

As argued by Kromhout et $a l^{7}$, promotion of healthy dietary habits in the CIS may help to reverse these trends in morbidity and mortality. However, such promotion requires a knowledge of the pre-existing beliefs, attitudes and barriers to healthy eating. As noted at the 1992 International Conference on Nutrition, and stated by Gibney et $\mathrm{al}^{8}$, 'an understanding of the general public's attitudes towards and beliefs about food, nutrition and health is necessary for the formulation and effective implementation of nutrition guidelines and promotion of healthy eating'. This need prompted the development of the Institute of European Food Studies' Pan-EU Survey of Consumer Attitudes to Food, Nutrition and Health ${ }^{8}$, which was the source of the questions used in our survey.

To the best of our knowledge, this pilot study, in which we surveyed adult subjects from one of the large cities in Ukraine, is the first study to examine influences on food choice, and attitudes towards, barriers to and information sources on healthy eating in a CIS country.

\section{Methods and materials}

\section{Subjects}

A convenience sample of 212 females and 84 males (aged 18-55 years) living in Lviv city, Ukraine, was recruited. Two groups were recruited by college and university professors through oral advertisements made in classes. The first group were students $(n=162)$ attending Western Ukrainian Collegium (legal assistant and marketing/manager majors) and Lviv State Academy of Forestry (ecology and forestry engineering majors). The second ( $n=41)$ consisted of highly educated but unemployed subjects (for example unemployed engineers and librarians) attending government-sponsored courses in computer literacy. These latter subjects were classified as 'unemployed' for the purposes of this study. Completion of the survey was not one of the class requirements and no course credit was given for participation.

A third group of subjects $(n=87)$ were recruited by social networking (word of mouth) through personal contacts (friends, family, former coworkers) of the first author. These people were asked to disseminate questionnaires to as many others as possible. These subjects came from a variety of educational and occupational backgrounds (school and college teachers, bank employees, accountants, doctors, nurses, engineers, salespersons, blue-collar workers, etc.). The three groups recruited were similar in that they were urban dwellers, and either highly educated or seeking higher education.

The subjects filled in the questionnaires at home and returned them upon completion. Of the 301 questionnaires returned, 5 (1.7\% of the total returned) were not used because of missing data or because they were filled out incorrectly. Two of these were filled out by males and three by females.

The remaining subjects were classified by sex, age group (18-25; 26-35; 36-55 years), education (secondary and 1-2 years beyond secondary; tertiary; student) and, for non-students, employment status. The average ages in education groups were: students, 18.6 years; secondary or 1-2 years beyond, 32.5 years; tertiary, 35.1 years. The 
Table 2 Percentage of the subjects, classified by demographics, selecting each factor as being among their three most important influences on food choice

\begin{tabular}{|c|c|c|c|c|c|}
\hline & Quality/freshness & Price & Taste & Trying to eat healthily & Family preferences \\
\hline Total & 80.1 & 58.4 & 46.6 & 34.1 & 24.3 \\
\hline Sex & NS & NS & * & NS & NS \\
\hline Male & 78.6 & 51.2 & 56.0 & 29.8 & 25.0 \\
\hline Female & 80.7 & 61.3 & 42.9 & 35.9 & 24.1 \\
\hline Age (years) & $\star *$ & * & $\star *$ & NS & *** \\
\hline $18-25$ & 82.0 & 53.9 & 54.5 & 31.5 & 16.9 \\
\hline $26-35$ & 88.7 & 56.5 & 38.7 & 45.2 & 30.7 \\
\hline $36-55$ & 64.3 & 75.0 & 30.4 & 30.4 & 41.1 \\
\hline Education & NS & NS & $\star \star$ & NS & *** \\
\hline Secondary or $1-2$ years beyond & 67.7 & 64.5 & 22.6 & 32.3 & 41.9 \\
\hline Tertiary & 80.6 & 64.1 & 38.8 & 40.8 & 32.0 \\
\hline Student (college or university) & 82.1 & 53.7 & 56.2 & 30.3 & 16.1 \\
\hline Employment status (non-students) & NS & NS & NS & NS & NS \\
\hline Employed & 78.2 & 58.6 & 37.9 & 40.2 & 34.5 \\
\hline Unemployed & 76.6 & 74.5 & 29.8 & 36.2 & 34.0 \\
\hline
\end{tabular}

Significance levels for age, sex, education and occupation effects (chi-square test): ${ }^{* \star} P<0.001$; ${ }^{\star \star} P<0.01 ;{ }^{*} P<0.05$; NS, not significant.

average age in the employed and unemployed groups was the same, 34.5 years. Data on gender, age and education level in the sample are provided in Table 1.

Data collection was carried out between July and September 1998. The study was approved by the University Committee on Human Subjects, Cornell University.

\section{Questionnaire}

The questions used for the analyses presented in this paper were administered as part of a large questionnaire directed at assessment of food consumption patterns, food preferences and fitness beliefs. The questionnaire included a consent form, questions concerning the participant's date of birth, educational level and occupation, and questions adopted from the Pan-EU Survey of Consumer Attitudes to Food, Nutrition and Health ${ }^{8}$, directed at identifying the major perceived influences on food choice, the perceived barriers to healthy eating, and the sources of information on healthy eating used and trusted by the participants (see Appendix). The questionnaire was translated into Ukrainian by the first author and then back-translated by a second independent bilingual Ukrainian speaker who had no knowledge of the original questions. No data regarding the validity or reliability of this instrument were available from the PanEU Survey, and no pretesting of the questions had previously been done in Ukraine.

\section{Statistical analysis}

Descriptive statistics (percentage of subjects, and mean score for responses scored on a four-point scale), chisquare statistics and non-parametric tests (Mann-Whitney
U and Kruskal-Wallis tests) were performed using JMP 3.1, a statistical package from the SAS Institute.

\section{Results}

\section{Influences on food choice}

The most important influence on food choice for $52.4 \%$ of the subjects was 'quality/freshness', followed by 'taste' (13.5\% of subjects), 'price' (10.8\%), 'trying to eat healthily' (9.8\%) and 'family preferences' (4.7\%). The other influences were mentioned by fewer than 10 subjects each: 'availability' (2.7\%), 'slimming' (1.7\%), 'habit' (1.4\%), 'content of additives' (1.0\%), 'someone else decides' $(0.7 \%)$, 'convenience' $(0.7 \%)$, 'prescribed diet' $(0.3 \%)$ and 'religion/culture' $(0.3 \%)$. Nobody mentioned 'presentation/packaging' and 'vegetarian' as the most important influence.

Table 2 provides the percentages of subjects who picked each of the five most commonly mentioned influences, as being amongst the top three influences on their food choice. Influences selected by fewer than $15 \%$ of the subjects included 'availability' (14.2\%), 'habit' $(12.2 \%)$, 'convenience' (10.5\%), 'slimming' (7.8\%), 'content of additives' (6.1\%), 'someone else decides' (3.0\%), 'prescribed diet' (1.0\%), 'religion/culture' (1.0\%) and 'vegetarian' $(0.7 \%)$. Nobody selected 'presentation/packaging' as being amongst their three most important influences in food choice.

Males and females differed only in the importance of taste in food choice, whereas age differences were significant for all the major factors except 'trying to eat healthily'. Not surprisingly, family considerations were more important for the older group than for the younger group, whereas taste was more important than other 
Table 3 Percentage of subjects who use each source of information on healthy eating, classified by demographics

\begin{tabular}{|c|c|c|c|c|c|c|c|c|c|c|}
\hline & $\begin{array}{l}\text { Relatives/ } \\
\text { friends }\end{array}$ & $\begin{array}{c}\text { Food } \\
\text { packages }\end{array}$ & Books & $\begin{array}{l}\text { Newspapers/ } \\
\text { magazines }\end{array}$ & Advertising & $\begin{array}{l}\text { Health } \\
\text { professionals }\end{array}$ & $\begin{array}{c}\text { TV } \\
\text { s programmes }\end{array}$ & $\begin{array}{c}\text { Government } \\
\text { agencies }\end{array}$ & $\begin{array}{l}\text { Western } \\
\text { magazines }\end{array}$ & $\begin{array}{l}\text { Leaflets in } \\
\text { clinics }\end{array}$ \\
\hline Total & 64.5 & 48.7 & 48.7 & 44.6 & 40.4 & 35.1 & 30.7 & 26.4 & 17.6 & 12.5 \\
\hline Sex & * & NS & ** & NS & NS & NS & NS & * & NS & NS \\
\hline Male & 53.6 & 48.8 & 35.7 & 38.1 & 46.4 & 29.8 & 30.7 & 34.5 & 14.3 & 8.3 \\
\hline Female & 68.9 & 48.6 & 53.8 & 47.2 & 38.2 & 37.3 & 31.0 & 23.1 & 18.9 & 14.2 \\
\hline Age (years) & NS & NS & 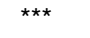 & ** & NS & NS & NS & NS & NS & NS \\
\hline $18-25$ & 64.0 & 47.8 & 39.9 & 38.2 & 46.3 & 39.9 & 33.2 & 26.4 & 19.1 & 14.6 \\
\hline $26-35$ & 64.5 & 50.0 & 67.7 & 61.3 & 38.7 & 30.7 & 25.8 & 30.7 & 14.5 & 9.7 \\
\hline $36-55$ & 66.1 & 50.0 & 55.4 & 46.4 & 33.9 & 25.0 & 28.6 & 21.4 & 16.1 & 8.9 \\
\hline Education & NS & NS & *** & $\star *$ & NS & NS & NS & NS & NS & NS \\
\hline $\begin{array}{l}\text { Secondary or 1-2 } \\
\text { years beyond }\end{array}$ & 74.2 & 54.8 & 41.9 & 41.2 & 45.2 & 25.8 & 19.4 & 16.1 & 9.7 & 6.5 \\
\hline Tertiary & 66.0 & 46.6 & 67.0 & 58.3 & 35.0 & 31.1 & 32.0 & 28.2 & 19.4 & 10.7 \\
\hline $\begin{array}{l}\text { Student (college or } \\
\text { university) }\end{array}$ & 61.7 & 48.8 & 38.3 & 35.8 & 43.2 & 39.5 & 32.1 & 27.2 & 17.9 & 14.8 \\
\hline $\begin{array}{l}\text { Employment status } \\
\text { (non-students) }\end{array}$ & NS & NS & NS & NS & NS & NS & NS & NS & NS & NS \\
\hline Employed & 67.8 & 50.6 & 57.5 & 56.3 & 40.2 & 31.0 & 25.3 & 24.1 & 16.1 & 6.9 \\
\hline Unemployed & 68.1 & 44.7 & 68.1 & 53.2 & 31.9 & 27.7 & 36.2 & 27.7 & 19.2 & 14.9 \\
\hline
\end{tabular}

Significance levels for age, sex, education and occupation effects (chi-square test): ${ }^{* \star} P<0.001 ;{ }^{* \star} P<0.01 ;{ }^{*} P<0.05$; NS, not significant.

considerations for the young. Employment status had no significant effect on the number of subjects selecting a given influence.

\section{Sources of information used to obtain information on bealthy eating}

Data for subjects choosing each information source are presented in Table 3 .

\section{Trust in information sources}

Table 4 shows the data concerning trust in information sources. Note that if we take 2.5 as the borderline between trusting and distrusting (a score of 2.5 lies midway between 'tend to trust' and 'tend to distrust'), then all non-media sources (health professionals, relatives/friends, government agencies and food packages) tended to be trusted, while all media sources tended to not be trusted.

Table 4 Mean scores for trust ${ }^{\mathrm{a}}$, and percentage of subjects who trust ${ }^{\mathrm{b}}$ (in parentheses), in each of the sources of information on healthy eating, classified by demographics

\begin{tabular}{|c|c|c|c|c|c|c|c|c|}
\hline & $\begin{array}{c}\text { Health } \\
\text { professionals }\end{array}$ & $\begin{array}{l}\text { Relatives/ } \\
\text { friends }\end{array}$ & $\begin{array}{c}\text { Government } \\
\text { agencies }\end{array}$ & $\begin{array}{c}\text { Food } \\
\text { packages }\end{array}$ & $\begin{array}{c}\text { Newspapers/ } \\
\text { magazines }\end{array}$ & $\begin{array}{l}\text { Western } \\
\text { magazines }\end{array}$ & $\begin{array}{c}\text { TV } \\
\text { programmes }\end{array}$ & Advertising \\
\hline Total & $3.27(92.2)$ & $3.03(84.5)$ & $2.70(64.9)$ & $2.61(63.9)$ & $2.44(50.0)$ & $2.35(46.0)$ & $2.34(42.9)$ & $2.10(28.4)$ \\
\hline Sex & NS & NS & NS & NS & NS & NS & NS & NS \\
\hline Male & $3.32(92.9)$ & $2.95(78.6)$ & $2.74(64.3)$ & $2.61(65.5)$ & $2.42(45.2)$ & $2.32(42.9)$ & $2.39(45.2)$ & 2.19 (35.7) \\
\hline Female & $3.25(92.0)$ & $3.06(86.8)$ & $2.68(65.1)$ & $2.61(63.2)$ & $2.45(51.9)$ & $2.36(47.7)$ & $2.32(42.0)$ & $2.07(25.5)$ \\
\hline Age (years) & *** & NS & ${ }^{*}$ & NS & NS & NS & ${ }^{*}$ & ** \\
\hline $18-25$ & $3.40(94.4)$ & $3.06(84.3)$ & $2.79(68.5)$ & $2.61(63.5)$ & $2.44(48.9)$ & $2.37(47.8)$ & $2.42(50.0)$ & $2.22(36.5)$ \\
\hline $26-35$ & $3.00(85.5)$ & $2.95(80.7)$ & $2.58(61.3)$ & $2.65(64.5)$ & $2.60(58.1)$ & $2.42(51.6)$ & 2.27 (32.3) & $1.97(16.1)$ \\
\hline $36-55$ & $3.12(92.9)$ & $3.04(89.3)$ & $2.54(57.1)$ & $2.57(64.3)$ & $2.27(44.6)$ & $2.20(33.9)$ & $2.16(32.1)$ & $1.89(16.1)$ \\
\hline Education & 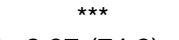 & NS & ${ }^{*}$ & NS & NS & NS & $\star * * *$ & 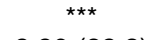 \\
\hline Secondary or 1-2 years beyond & $2.97(74.2)$ & $3.10(87.1)$ & $2.61(61.3)$ & $2.61(64.5)$ & $2.26(35.5)$ & $2.16(38.7)$ & $2.23(32.3)$ & 2.26 (32.3) \\
\hline Tertiary & 3.09 (93.2) & $2.98(85.4)$ & 2.55 & $2.52(60.2)$ & $2.50(56.3)$ & $2.33(43.7)$ & $2.16(29.1)$ & $1.83(11.7)$ \\
\hline Student (college or university) & $3.44(95.1)$ & $3.05(83.3)$ & $2.81(69.8)$ & $2.66(66.1)$ & $2.44(48.8)$ & $2.40(48.8)$ & $2.48(53.7)$ & $2.25(38.3)$ \\
\hline Employment status (non-students) & ${ }^{*}$ & NS & NS & ${ }^{*}$ & NS & NS & NS & NS \\
\hline Employed & $3.14(92.0)$ & $2.95(85.1)$ & $2.51(57.5)$ & $2.67(69.0)$ & $2.46(52.9)$ & $2.32(40.2)$ & $2.16(27.6)$ & $1.98(16.1)$ \\
\hline Unemployed & $2.91(83.0)$ & $3.11(87.2)$ & $2.68(61.7)$ & $2.32(46.8)$ & $2.40(48.9)$ & $2.23(46.8)$ & $2.19(34.0)$ & $1.85(17.0)$ \\
\hline
\end{tabular}


Table 5 Mean scores of agreement ${ }^{\mathrm{a}}$, and percentage of the subjects who agree ${ }^{\mathrm{b}}$ (in parentheses), with the statements 'I frequently try to get information on healthy eating'; 'I usually do not think of the nutritional aspects of the food I eat' and 'I do not need to make changes to the food I eat, as it is already healthy enough', classified by demographics

\begin{tabular}{|c|c|c|c|}
\hline & Often seek information & Do not think of nutrition & Do not need to change \\
\hline Total & $2.87(75.0)$ & $2.53(50.3)$ & $2.57(53.4)$ \\
\hline Sex & ** & $\star \star \star ~$ & $\star \star \star *$ \\
\hline Male & $2.61(65.5)$ & $2.93(65.5)$ & $2.98(71.4)$ \\
\hline Female & $2.98(78.7)$ & $2.37(44.3)$ & $2.41(46.2)$ \\
\hline Age (years) & NS & * & NS \\
\hline $18-25$ & $2.91(76.4)$ & $2.56(52.2)$ & $2.67(57.3)$ \\
\hline $26-35$ & $2.94(77.4)$ & $2.27(35.5)$ & $2.39(43.6)$ \\
\hline $36-55$ & $2.68(67.9)$ & $2.70(60.7)$ & $2.45(51.8)$ \\
\hline Education & NS & NS & NS \\
\hline Secondary or 1-2 years beyond & $2.97(80.6)$ & $2.58(48.4)$ & $2.26(38.9)$ \\
\hline Tertiary & $2.82(70.9)$ & $2.44(45.6)$ & $2.53(43.4)$ \\
\hline Student (college or university) & $2.89(76.5)$ & $2.57(53.7)$ & $2.65(56.2)$ \\
\hline Employment status (non-students) & * & NS & NS \\
\hline Employed & $2.76(69.0)$ & $2.48(48.2)$ & $2.51(52.9)$ \\
\hline Unemployed & $3.02(80.8)$ & $2.45(42.6)$ & $2.40(44.7)$ \\
\hline
\end{tabular}

\section{Perceived need to alter eating habits}

Data on responses to statements concerning a perceived need to alter eating habits are presented in Table 5. Statements concerning information seeking and need to change were unrelated. However, the statement 'I usually do not think of the nutritional aspects of the food I eat' was significantly related to the other two statements: participants who agreed that they do not think about nutrition were also more likely to agree that they do not need to change their diet $(P<0.0001$, chi-square test $)$ and to disagree that they often seek information on healthy eating $(P<0.001$, chi-square test $)$.

\section{Perceived barriers to bealthy eating}

Almost two-thirds of the subjects chose 'price of healthy foods' as a barrier, followed by 'giving up foods I like' (chosen by 44.9\%), 'busy lifestyle' (39.9\%) and 'irregular working hours' (30.1\%). Other individual barriers mentioned by more than $20 \%$ of participants were: 'lack of willpower' (25.3\%), 'unappealing food' (24.7\%), 'healthy options not available in stores' $(24.0 \%)$, 'do not want to change my eating habits' (22.0\%), 'not enough food to satisfy hunger' (21.3\%) and 'experts keep changing their minds' (20.6\%). Fourteen per cent of the subjects stated that they 'do not know enough about healthy eating'.

Table 6 Percentage of the subjects, classified by demographics, selecting each category of barriers to healthy eating

\begin{tabular}{|c|c|c|c|c|c|c|c|c|c|}
\hline & $\begin{array}{c}\text { Cost of } \\
\text { food }\end{array}$ & $\begin{array}{l}\text { Lack of } \\
\text { time }\end{array}$ & $\begin{array}{c}\text { Self- } \\
\text { control }\end{array}$ & $\begin{array}{l}\text { Selection } \\
\text { influences }\end{array}$ & $\begin{array}{c}\text { Lack of } \\
\text { knowledge }\end{array}$ & $\begin{array}{l}\text { Unpleasant } \\
\text { foods }\end{array}$ & $\begin{array}{l}\text { Resistance } \\
\text { to change }\end{array}$ & $\begin{array}{c}\text { Food } \\
\text { preparation }\end{array}$ & $\begin{array}{l}\text { Influence } \\
\text { of others }\end{array}$ \\
\hline Total & 64.5 & 54.7 & 53.7 & 41.2 & 32.1 & 30.4 & 30.1 & 26.4 & 22.0 \\
\hline Sex & ** & ** & NS & NS & NS & NS & NS & NS & NS \\
\hline Male & 50.0 & 63.1 & 50.0 & 38.1 & 31.0 & 36.9 & 31.0 & 32.1 & 17.9 \\
\hline Female & 70.3 & 51.4 & 55.2 & 42.5 & 32.6 & 27.8 & 29.7 & 24.1 & 23.6 \\
\hline Age (years) & NS & NS & NS & NS & NS & NS & NS & * & NS \\
\hline $18-25$ & 60.1 & 55.1 & 58.4 & 43.8 & 35.4 & 32.6 & 33.7 & 32.0 & 19.1 \\
\hline $26-35$ & 67.7 & 59.7 & 43.6 & 35.5 & 25.8 & 29.0 & 21.0 & 21.0 & 32.3 \\
\hline $36-55$ & 75.0 & 48.2 & 50.0 & 30.3 & 28.6 & 25.0 & 28.6 & 14.3 & 19.6 \\
\hline Education & NS & NS & NS & NS & NS & NS & NS & * & NS \\
\hline Secondary or $1-2$ years beyond & 74.2 & 45.2 & 54.8 & 41.9 & 25.8 & 22.6 & 22.6 & 12.9 & 32.3 \\
\hline Tertiary & 68.9 & 56.3 & 46.6 & 39.8 & 30.1 & 29.1 & 24.3 & 21.4 & 22.3 \\
\hline Student (college or university) & 59.9 & 55.6 & 58.0 & 42.0 & 34.6 & 32.7 & 35.2 & 32.1 & 19.8 \\
\hline Employment status (non-students) & NS & $\star * *$ & NS & NS & NS & NS & NS & NS & NS \\
\hline Employed & 67.8 & 64.4 & 44.8 & 37.9 & 32.2 & 25.3 & 28.7 & 19.5 & 27.6 \\
\hline Unemployed & 74.5 & 34.0 & 55.3 & 44.7 & 23.4 & 31.9 & 14.9 & 19.2 & 19.2 \\
\hline
\end{tabular}

Significance levels for age, sex, education and occupation effects (chi-square test): ${ }^{\star \star \star} P<0.001$; ${ }^{\star \star} P<0.01 ;{ }^{*} P<0.05$; NS, not significant. 
Students mentioned this barrier more frequently than non-students $(20.4 \%$ and $6.7 \%$, respectively; $P<0.001$, chi-square test). Only $1.7 \%$ of respondents reported not having any difficulties in eating a healthy diet.

Data on barrier categories are presented in Table 6.

\section{Relationships between barrier categories and factors important in food choice}

With respect to food choice factors, as evaluated by the chisquare test, those who mentioned 'price' as an important factor in food choice were more likely to mention the 'cost of food' barrier category $(P<0.0001)$, and less likely to mention the category 'influence of other people' $(P<$ 0.05). Those who mentioned 'taste' as important, were more likely to mention 'unpleasant foods' as a barrier category $(P<0.0001)$, and less likely to mention 'cost of food' $(P<0.05)$. Subjects who selected 'family preferences' were more likely to mention 'influence of other people' $(P<0.01)$ and less likely to mention 'unpleasant foods' $(P<0.05)$ as barriers. 'Trying to eat healthily' was not related to any of the barrier categories.

\section{Discussion}

The pilot study presented here is the first survey of a Ukrainian population concerning healthy eating. We used questions derived from the Pan-EU Survey of Consumer Attitudes to Food, Nutrition and Health, in order to compare responses obtained in this Ukrainian population with responses obtained in Western Europe. Because the population we surveyed is becoming increasingly exposed to western influences, while at the same time experiencing food insecurity, these data can provide a glimpse of the health and eating issues considered important by a population in socioeconomic and cultural transition.

\section{The Ukrainian situation and choice of subjects}

In order to put our subjects' responses in context, we should point out, first, that purchasing power and food security have decreased dramatically in Ukraine in the past 6-7 years. The average monthly income at the time of study was about US\$70, and according to some estimates people spend $60 \%$ or more of their income on food ${ }^{9}$, compared with $22 \%$ spent in the countries of the $\mathrm{EU}^{10}$. Second, there is a lack of governmental effort to provide health professionals and the general population with upto-date nutrition information. Many health professionals still use the outdated recommendations of the former USSR, which emphasize the healthiness of animal products and promote high calorie and protein intakes. On the other hand, there is a major influx of western media that often carry contradictory and confusing messages, for example, about the healthiness of junk food such as candy bars or chocolate spreads. The emerging commercial literature on 'healthy' eating promotes diets and other approaches to slimming, such as the use of herbal additives. Nowhere is there an emphasis on health and the avoidance of malnutrition $^{11}$. Finally, at present the Ukrainian food market has much less product variety (especially with respect to semiprepared and ready-to-eat meals) than food markets of western countries. Commercial 'lite' or 'low-fat' foods are either unavailable to, or unaffordable for, the general population.

We had access to a limited population of college students and people with a high education level. These respondents were to an extent self-selected - the questionnaire as a whole was long, so people had to find the time and the will to complete and return it. Therefore the likely bias would be towards people who had both time to fill out the survey and an interest in the subject. Clearly this population cannot be construed as representative of the Ukrainian population as a whole, and we would not suggest that the findings presented here can be extended to the whole population.

Nevertheless, an advantage of surveying this highly educated, urban population is that these people, more than (for example) a rural population, are affected by the socioeconomic transition described above. Urban populations, and especially educated people in the professions, have experienced drastic decreases in real income, coupled with increasing opportunities for exposure to Western European influences. At the same time they are dependent on food stores and farmers' markets, where they are also exposed to imported food products. They are therefore likely to experience the conflict presented by the twin influences of economic collapse and of the influx of western commodities and ideas. By contrast, rural life has remained relatively stable, and rural populations eat primarily self-produced foods, and so are less likely to experience the same degree of food insecurity.

\section{The Pan-EU Survey}

We chose the Pan-EU Survey as the source for our questions because the questions had already been developed for the study of populations across a wide range of ethnicity, prosperity and eating habits, and because it enabled us to compare our findings with data obtained in Western European populations.

We realize that the results of this pilot study may not be fully comparable to those obtained in the Pan-EU Survey, insofar as the sampling and methodology were different. While we studied a relatively small convenience sample of urban, mostly young, female, and highly educated subjects, the samples used in the Pan-EU Survey were designed to be nationally representative ${ }^{12}$. Further, in our study, the subjects filled in the questionnaires individually, without an interviewer's assistance, whereas a face-to-face interview-assisted technique was used in the Pan-EU Survey. Despite these differences in survey technique, it is instructive to examine the similarities and differences between the results obtained in the two surveys. 


\section{Similarities and differences between the Pan-EU and Ukraine results}

\section{Influences on food choice}

Given the peculiarities of both the Ukrainian situation and of the subject sampling we carried out, it was interesting to observe that the general pattern and even the order of importance of major perceived influences on food choice observed in our study were similar to those found in the $\mathrm{EU}^{13}$. The same five major influences on food choice were 'quality/freshness' (mentioned by $80 \%$ of our Ukrainian subjects and by $75 \%$ of subjects in the EU), 'price' (mentioned by $58 \%$ and $43 \%$, respectively), 'taste' ( $47 \%$ and 38\%), 'trying to eat healthily' (34\% and 32\%) and 'family preferences' (24\% and 29\%).

Similar to that observed in the EU, taste was more salient in men's food choice, whereas women tended to mention health and price influences more frequently.

Given the Ukrainian economic situation, it is not surprising that a higher percentage of Ukrainian subjects than EU subjects selected 'price' as an important influence. Although minor influences for both, 'availability' was chosen by more Ukrainian subjects than EU subjects (14\% vs 6\%) and 'habit' by fewer Ukrainian than EU subjects (12\% vs $21 \%$ ), probably because the variety of foods available to consumers in Ukraine is an issue, whereas habit may play less of a role when price and availability are limiting factors.

Contrary to what was found in the EU, subjects aged $36-55$ years were much more concerned about price and less about quality/freshness of food than younger groups. It may be that middle-aged people with families are more aware and concerned about food security than are younger subjects, who are more likely to be single and receive support from their parents. We also observed that the importance of family preferences in food choice increased with increasing age, whereas the importance of taste decreased.

\section{Information on bealthy eating}

Seventy-five per cent of the subjects in our sample reported that they often seek information on healthy eating, a value much higher than the EU average (47\%); only $3 \%$ of the subjects stated that they do not get any information on healthy eating, compared with $15 \%$ in the $\mathrm{EU}^{14}$. This difference may be due in part to characteristics of the Ukrainian sample, although overreporting cannot be excluded.

Relatives and friends were the major source of information on healthy eating among these Ukrainians, used by $64 \%$ compared to only $22 \%$ of the EU subjects ${ }^{14}$ and $12 \%$ of a US population ${ }^{15}$. Importantly, relatives and friends were not only a highly used, but also a highly trusted, source (by $85 \%$ of the subjects, second only to health professionals, who were trusted by 92\%), especially by females. It may be that, where information sources are scarce, confusing and unreliable, people tend to rely on word of mouth from individuals whom they trust. Given that the influence of relatives/friends tends to affect actual behaviour more than that of other sources (media, advertising, education, etc.) ${ }^{16}$, it is clear that the content and rationale of this 'word of mouth' requires further careful investigation.

Another source often used by our Ukrainian population but not in the EU was books (49\% vs 15\%). This difference may be due to the high average educational level of our population, because, as was observed in the EU, subjects with tertiary education in our Ukrainian sample used and trusted printed sources (newspapers, magazines, books) more than did other groups.

Mass media sources (TV, newspapers, magazines) were also reported to be widely used, although western magazines, which are highly priced, were used by only $18 \%$ of the subjects. It was clear that the mass media are not perceived by these Ukrainians as major information sources, as is the case for consumers in the USA and Western Europe $\mathrm{E}^{14,15,17}$, although the levels of trust in magazines and newspapers were similar in both surveys. Advertising was used by $40 \%$ in Ukraine vs $17 \%$ in the EU, although it was the least trusted source in both (trusted by $28 \%$ and $25 \%$ of subjects, respectively). Use of and trust in both advertising and TV was highest in the youngest age group (18-25 years), suggesting that, as elsewhere, these media may be useful in reaching the young.

As in western countries, a relatively small percentage of these Ukrainian subjects used health professionals, government sources or leaflets in clinics to obtain nutrition information. Furthermore, Ukrainians tended to trust less in governmental sources than did EU subjects (65\% vs 80\%). Surprisingly, use of health professionals and leaflets in clinics decreased with increasing age. This finding should be a matter for further study, because the older population is the one at most immediate risk for diet-related health problems.

\section{Need to change}

Forty-seven per cent of the subjects (females 54\%; males $29 \%$ ) in our sample said they needed to change to a more healthy diet, compared with only $29 \%$ in the EU sample ${ }^{18}$ (no gender difference). This finding suggests that a substantial proportion of the young educated Ukrainian population, particularly women, may be open to the idea of dietary change. The percentage of subjects in our study that usually do not think of the nutritional aspects of food they eat ( $50 \%$; males $66 \%$, females $44 \%$ ) was similar to that observed in the EU (49\%; males 59\%, females 45\%). Numerous studies have documented that women are more concerned about healthy eating, and have better nutritional knowledge and a more positive attitude towards dietary change ${ }^{19-23}$.

More research is needed to differentiate those who do not perceive the need to change because their diet is 
healthy already from those who do not want to change because they are unconcerned about nutrition or because of some other barrier to adopting a healthy $\operatorname{diet}^{18}$.

\section{Barriers to bealthy eating}

'Cost of food' was the most frequently mentioned barrier to healthy eating (mentioned by $65 \%$ of our respondents), whereas this barrier was by far less salient in the EU populations $^{24}$ (mentioned by only 15\%). This finding is not surprising given the difference in the economic situation between Ukraine and the EU countries. However, this finding also suggests that these Ukrainian subjects perceive a healthy diet to be more expensive than their present diet, which is not necessarily the case. A potential strategy for nutrition education for this population should address ways to make inexpensive yet healthy food choices and how to stretch the value of a limited food budget in order to include a variety of nutritious foods, while limiting the purchase of foods with low nutritional value.

'Lack of time', which was the second most frequently mentioned barrier (by 55\%) was also among the most salient in the EU sample ${ }^{24}$ (mentioned by 33\%), with a similar pattern of sociodemographic distribution. Another frequently mentioned barrier characteristic of the Ukrainian situation was 'selection influences' (mentioned by $41 \%$ compared with $14 \%$ of the EU sample). This finding again points out the need to help people make healthy food choices when the selection and supply of foods is limited.

'Self-control' and 'resistance to change' were commonly mentioned barrier categories in both our study and the Pan-EU Survey (by 54\% and 30\% of these Ukrainians, respectively, compared with $33 \%$ and $21 \%$ of the EU subjects). In our sample we did not observe any consistent gender or age patterns to these factors, although students tended to mention these two barrier categories most frequently. As expected, students in our study were also most likely to mention 'food preparation' and least likely to mention 'influence of others' as barriers.

Interestingly, only 20\% of students and $7 \%$ of nonstudents in our sample mentioned 'do not know enough about healthy eating' as a barrier. This low percentage begs a question concerning the actual content of this population's nutrition knowledge.

\section{Conclusions}

This pilot study has provided an initial glimpse into issues surrounding healthy eating in a population from a CIS country. Some issues, such as the price of food, appear to be dictated by the current economic situation peculiar to Ukraine, while others seem to be characteristic of European populations in general. Specific strategies for developing nutrition education programmes for Ukraine will clearly have to wait until a more representative sample is obtained. However, these data point to priority areas for future in-depth research and policy planning.

The importance of word of mouth in transmitting nutrition information in this population cannot be overestimated, especially when contrasted with its relative lack of importance in Western European populations. A long tradition of mistrust of official sources, coupled with reliance on family and friends for mutual support, means that it may be important to devise ways to make use of this 'grapevine' to promote healthy eating in the face of limited food security. While we recognize that financial and structural barriers may preclude this type of programme, a model for such an approach may be the US Expanded Food and Nutrition Education Program, which is designed to make use of neighbourhood paraprofessionals to promote healthy eating on a low budget.

\section{Acknowledgements}

The research was supported by a Grant for Research from the Division of Nutritional Sciences, Cornell University, and the Lydia Leuder Darling Scholarship from the College of Human Ecology, Cornell University.

\section{References}

1 Shkolnikov VM, Mesle F, Vallin J. Recent trends in life expectancy and causes of death in Russia, 1970-1993. Premature Death in the New Independent States. Washington, DC: National Academy Press, 1997: 34-65.

2 Leon DA, Chenet L, Shkolnikov VM, et al. Huge variation in Russian mortality rates 1984-94: artefact, alcohol or what? Lancet 1997; 350: 383-8.

3 Cockerham WC. The social determinants of the decline of life expectancy in Russia and Eastern Europe: a lifestyle explanation. J. Health Soc. Behav. 1997; 38: 117-30.

4 Popkin B, Zohoori N, Kohlmeier L, Baturin A, Martinchik A, Deev A. Nutritional risk factors in the former Soviet Union. Premature Death in the New Independent States. Washington, DC: National Academy Press, 1997: 314-34.

5 Ministry of Health Care of the USSR. Normy fiziologicheskih potrebnostei $v$ pischevykh veschestvakh $i$ energii dlia razlichnykh grup naselenia SSSR [Norms of Physiologic Requirements in Nutrients and Energy for the Different Population Groups of the USSR]. Moscow: Ministry of Health Care of the USSR, 1991.

6 National Research Council, Food and Nutrition Board Recommended Daily Allowances, 10th edn. Washington, DC: National Academy Press, 1989.

7 Kromhout D, Bloemberg B, Doornbos G. Reversibility of the rise in Russian mortality rates. Lancet 1997; 350: 378.

8 Gibney MJ, Kearney M, Kearney JM. Introduction: IEFS panEU survey of consumer attitudes to food, nutrition and health. Eur. J. Clin. Nutr. 1997; 51(Suppl. 2): S2.

9 Statistical Yearbook of Ukraine. Kyiv, Ukraine: Ukrainian Encyclopedia, 1997.

10 OECD. Purchasing Power Parities and Real Expenditure, Vol. 2. Paris: Organization for Economic Cooperation and Development, 1996.

11 Popkin BM. The nutrition transition and its health implications in lower-income countries. Public Health Nutr. 1998; 1: 5-21.

12 Kearney M, Kearney JM, Gibney MJ. Methods used to conduct a survey on consumer attitudes to food, nutrition 
and health on nationally-representative samples of adults from each member state of the European Union. Eur. J. Clin. Nutr. 1997; 51(Suppl. 2): S3-7.

13 Lennernas M, Fjellstrom C, Becker W, et al. Influences on food choice perceived to be important by nationallyrepresentative samples of adults in the European Union. Eur. J. Clin. Nutr. 1997; 51(Suppl. 2): S8-15.

14 De Almeida MDV, Graca P, Lappalainen R, et al. Sources used and trusted by nationally-representative adults in the European Union for information on healthy eating. Eur. J. Clin. Nutr. 1997; 51(Suppl. 2): S16-22.

15 American Dietetic Association. Survey of American Dietary Habits, 1993 Executive Summary. Chicago, IL: American Dietetic Association, 1993.

16 Engel JF, Blackwell RD, Miniard PW. Consumer Behavior, 7th edn. Fort Worth: Dryden Press, 1993.

17 Krinke UB. Nutrition information topic and format preferences of older adults. J. Nutr. Educ. 1990; 22: 292.

18 Kearney M, Gibney M, Martinez JA, et al. Perceived need to alter food intake among representative samples of adults from all member states of the European Union. Eur. J. Clin. Nutr. 1997; 51(Suppl. 2): S30-5.

19 Brug J, van Assema P, Kok G, Lenderink P, Glanz K. Self-rated dietary intake: association with objective assessment of fat, psychological factors and intention to change. J. Nutr. Educ. 1994; 26: 218-23.

20 Hayes D, Ross CE. Concern with appearance, health beliefs and eating habits. J. Health Soc. Beh. 1987; 28: 120-30.

21 Shepherd R, Stockley L. Nutrition knowledge, attitudes, and fat consumption. J. Am. Diet. Assoc. 1987; 87: 615-19.

22 Towler G, Shepherd R. Application of Fishbein and Ajzen's expectancy value model to understanding fat intake. Appetite 1992; 18: 15-27.

23 Rappoport LH, Peters GP, Downey RG, McCann T, HuffCorsine L. Gender and age differences in food cognition. Appetite 1993; 20: 33-52.

24 Lappalainen R, Saba A, Holm L, Mykkanen H, Gibney MJ. Difficulties in trying to eat healthier: descriptive analysis of perceived barriers for healthy eating. Eur. J. Clin. Nutr. 1997; 51(Suppl. 2): S36-40.

\section{Appendix: questions used in the survey}

Question 1. The participants were asked to choose from a list of 15 factors that may potentially influence their food choice, the three factors which are most important, and to rank these factors in order of their importance (as described by Lennernas et $a l^{13}$ ). The 15 factors listed were: quality/freshness of food; habit; price of food; what my family or spouse eat; trying to eat healthy balanced diet; taste of food; convenience in preparation; presentation or packaging; slimming; vegetarian or other special eating habits; prescribed diet; content of artificial colours or preservatives; my cultural or religious background; someone else decides on most of the food that I eat.

Question 2. The subjects were asked which sources of information they use to obtain information on healthy eating out of a list of 10 sources plus a 'do not get any information' option, as described by De Almeida et al. ${ }^{14}$. Choosing multiple sources was allowed. An item labelled 'western magazines' and an item 'newspapers and nonwestern magazines' were included to assess the use of western versus non-western sources of information.
The other sources were: advertising in press and on the TV; information on food packages; doctors and other health professionals; books; information from government sources (e.g. Ministry of Health); TV news and other TV programmes; friends and relatives; leaflets in clinics.

Question 3. The participants were asked to indicate their level of trust in eight major information sources (the sources from question 2 minus 'books' and 'leaflets in clinics'). The responses were given a score using a fourpoint scale (trust fully $=4$, tend to trust $=3$, tend to distrust $=2$, distrust fully $=1$ ).

Questions 4-6. The subjects were presented with the following statements: 'I frequently try to get information on healthy eating' (question 4); 'I do not need to make changes to the food I eat, as it is already healthy enough' (question 5); 'I usually do not think of the nutritional aspects of the food I eat' (question 6). The responses were given a score using a four-point scale (strongly agree $=4$, tend to agree $=3$, tend to disagree $=2$, strongly disagree $=1$, as described by Kearney et al. ${ }^{18}$ ).

Question 7. The participants were presented with a list of 20 possible barriers (the items from the Pan-EU Survey 'storage facilities' and 'limited cooking facilities' were combined into one; the item 'healthy food more awkward to carry home from shops' was excluded), and asked to select those they would perceive as major difficulties when trying to eat more healthily. In addition to the list of barriers, the option 'no difficulty' was presented. Choosing multiple barriers was allowed. At the analysis stage, the barriers were grouped into nine categories (as described by Lappalainen et $a .^{24}$ ); a subject was classified as 'checked the category' if he/she checked at least one barrier in the given category. The categories (and barriers included) were:

- lack of time (irregular working hours; busy lifestyle);

- self-control (giving up foods that I like; lack of willpower);

- resistance to change (do not want to change my eating habits; too great a change from my current diet);

- food preparation (cooking skills; healthy foods are more perishable; lengthy preparation; limited storage and cooking facilities);

- cost of food (high price of healthy products);

- unpleasant foods (unappealing food; strange or unusual foods);

- influence of other people (feeling conspicuous among others; taste preferences of my family and friends);

- lack of knowledge/expert consensus (do not know enough about healthy eating; experts keep changing their minds);

- selection influences (limited choice when I eat out; healthy options not available in shop or market; not enough food to satisfy hunger). 